\title{
Exploring Effective Practices in Managing Distance Learning for Teaching Art and Design in Bahrain
}

\author{
Sama'a Al Hashimi \\ University of Bahrain, Sakheer, Kingdom of Bahrain \\ https://orcid.org/0000-0003-4355-8699
}

\begin{abstract}
As universities move to virtual learning, the need to explore the most effective practices for remotely teaching art and design students became very critical. It is very important to examine the strategies universities are using to efficiently transfer skills and knowledge and meet the needs of students through an online learning environment. Art and design classes involve hands-on activities and requirements that cannot easily be met in digital environments. Therefore, the study aims to investigate the creative approaches that art and design educators adopted to transition to remote teaching. The study involved conducting an online focus group with eleven art and design educators at The University of Bahrain to investigate the experiences, perceptions, and the challenges they faced while teaching art and design remotely during the Covid-19 Pandemic. The focus group engaged the educators in a semistructured discussion in order to gather qualitative data that would allow for a descriptive analysis of their online teaching experiences and the most effective approaches they implemented. Thus, the study is undertaken to determine the most effective practices that can be employed by educators to engage students and enhance the distance learning process in an art and design online environment. The findings suggested that the main challenges that are peculiar to art and design distance learning include difficulty in clearly seeing the value of the colors in a student's artwork on screen and the unavailability of features that support art and design remote teaching in the currently available learning management systems.
\end{abstract}

Keywords: distance learning; remote learning; art; design; Covid-19; Bahrain

\section{Introduction}

Although the challenges and experiences posed by the shift to remote learning during the Covid-19 pandemic vary widely across countries (Rasheed et al., 2020), disciplines, and universities, these challenges call for a fundamental rethinking of art and design education. For art and design educators, one-to-one interaction 
with students while they paint or design has always been essential to artmaking and teaching. Therefore, they may consider distance learning a transformative challenge without prior guidelines to inform their pedagogical practices. These educators have had to swiftly redesign, plan, and prepare their digital course content and experiment with various approaches to figure out how to mitigate learning loss and make remote learning work successfully for art and design education. As the pandemic has taken its course, several educational needs, challenges, and opportunities emerged for educators and students as they struggled to deal with some conceptual and artistic limits that the online environment imposed (Dilmaç, 2020; Tusiime et al., 2020). In light of this transformation and all its consequent challenges, Meyer and Norman (2020) urged design educators to "modify design pedagogy to accommodate the many different styles and goals of $21^{\text {st }}$ century design" (p.22). Hence, the main objective of this research is to analyze these challenges, needs, and opportunities and explore the most effective adaptive practices to facilitate and boost students' engagement, motivation, and participation during online learning in a virtual art and design classroom.

In the Kingdom of Bahrain, the implementation of distance learning in art and design higher education revealed several opportunities as well as challenges to universities, educators, and students. Fortunately, the basic foundations of distance learning exist in the Kingdom of Bahrain due to its robust technological infrastructure, which led many educational institutions to successfully face the crisis, transition to e-learning, and maintain the continuation of teaching. Nevertheless, art and design education in particular usually requires face-to-face and one-to-one interaction due to the nature of the hands-on activities and artworks it involves. Trying to teach fine arts remotely, for instance, posed some challenges to art instructors and their students.

Among the challenges that may have intensified during remote learning is getting students to participate and interact through the online platform. According to Mukuna and Aloka (2020) distance learning does not effectively allow for the affective interaction offered through face-to-face interaction. Digital platforms may create a communication and interaction barrier between art educators and students by making it hard for the educator to give feedback by pointing at certain elements on the students' canvases while they paint. Moreover, students may not know when to talk or express their opinions. For a discipline that involves artistic taste and requires aesthetic appreciation, students cannot visually determine, through body language and facial expressions, whether the instructor appreciates their artwork or not. Additionally, online discussions and presentations of artistic and graphic artworks, which are usually of a large file size, are often hindered by difficulties in students' access to technology and by technical issues and concerns. As a result, despite the universities' provision of the latest online educational platforms (such as Microsoft Teams and Blackboard), many educators may have to ask students to submit work over other channels such as google drive or email. This can also exacerbate if the educator lacks competency in using technology (Öçal et al., 2021), and lacks digital literacy or the ability to use distance learning technologies including learning management systems (LMS), massive open 
online courses (MOOCs), and other e-resources (Tabieh et al., 2021). This incompetency is considered an intrinsic challenge by Tusiime et al. (2020) who categorize the challenges that art and design educators face with distance education into intrinsic and extrinsic challenges, where intrinsic challenges relate to the educator while extrinsic challenges relate to the educational institution. In some cases, the incompetency may be due to resistance to the use of digital technologies by some educators who may not consider technology to be part of their fundamental teaching roles and goals (Tusiime et al., 2020).

Consequently, some questions surfaced with regards to several issues. Among them is the extent to which educators were ready and had the necessary resources to implement new strategies to teach art remotely. A study by Lapada et al. (2020), for instance, revealed a strong correlation between readiness for distance teaching and the length of teaching experience in addition to the specialization. Tusiime et al. (2020) confirmed the connection between the educators' specialization and their readiness for embracing technology in their pedagogical practices. They stated that some art teachers believe that technology is not compatible with art education and that it led to more opportunities for students to replicate art or to become reluctant to use their hands to draw. They also stated that the lack of competency may also be related to age as well as to the lack of time to learn and acquire digital skills, suggesting that higher educational institutions must give educators more time for professional development. According to Kini-Singh (2020), "Teachers across the world especially in the creative arts have found teaching online to be more work, requiring greater preparation and mental effort than in-person, classroom teaching" (p. 10). In addition, technical problems and lack of support to resolve them may discourage educators from employing digital tools in their pedagogical practices (Tusiime et al., 2020).

Additional issues and questions revolved around the extent of students' readiness and acceptance to learn art and design through distance learning, and the possibility of verifying that the artworks submitted are actually painted or designed by the students. Many other questions were also raised to explore which teaching and assessment approaches can be modified and adapted for remote learning, and which ones are less likely to be modified. In order to find answers to the above-mentioned questions and to investigate the challenges and opportunities that remote learning uncovered during this crisis, focus group discussions with academics at The University of Bahrain were conducted to gather data for this research.

\subsection{Research Problem and Significance}

Considering the exceptional circumstances that the world has gone through since the outbreak of the Covid-19 pandemic, remote education methods have been adopted by all educational institutions and at all educational levels in Bahrain. The main goals were to preserve the health and safety of citizens, to invest in and utilize all possible resources and digital platforms, and not to miss any opportunity to maintain the continuation of teaching and learning. However, because there was no time to predict or plan the crisis and its consequences on education, educators had to swiftly transition to online teaching without a 
common vision and systematic research-based guidelines and recommendations for this type of education (Kini-Singh, 2020). The implementation of distance learning in teaching art and design, especially fine art courses has posed several challenges due to its reliance on hands-on art-making activities and projects (Fleischmann, 2020), which require face-to-face interaction, continuous verbal feedback, and visual appreciation by the educator who is expected to guide, advise, and assess the students simultaneously while they paint or design. Many educators and students explored and experimented with a variety of approaches, tools, and innovative practices in an attempt to overcome these challenges (Meyer and Norman, 2020). These explorations may have led to successful experiences, outcomes, or at least potential opportunities. In order to ensure the success of teaching art and design remotely in Bahrain, this paper aims to identify and understand the educators' challenges, needs, experiences, and opportunities in an attempt to inform future practice and professional development.

\subsection{Research Questions}

1) What are the most inventive and effective pedagogical practices that art and design educators can employ to successfully integrate information technology in education in order to remotely teach art and design?

2) What are the positive and negative outcomes of remotely teaching art and design to higher education students in Bahrain?

3) What are educators' challenges, perceptions, and experiences with distance education in art and design higher education contexts?

\subsection{Research Objectives}

1) To examine international successful models and best practices of remote learning in art and design educational contexts

2) To examine art and design educators' experiences, challenges, and perceptions of teaching art and design virtually

3) To provide a set of recommendations that may inspire the creative and effective use of pedagogical practices and strategies by educators to guide their endeavors to remotely teach art and design

\section{Literature Review: An Exploration of International Practices, Approaches, and Technologies of Online Learning in Art and Design Education}

The coronavirus pandemic has started reconfiguring the teaching and learning process (Mukuna \& Aloka, 2020) and reshaping art and design education, and changing how students are educated (Muftahu, 2020; Nili et al., 2017; Reimers \& Schleicher, 2020). Although the crisis necessitated a hasty transition to e-learning (Kini-Singh, 2020), the solutions that educators around the world have explored and proposed for effective teaching could bring much-needed creativity and innovation ( $\mathrm{Li}$ et al., 2021). Therefore, exploring the opportunities and full potential of online learning in art and design education in this section is as important as examining the challenges and limitations.

Many art and design educators are endeavoring to find and learn ways to transition their hands-on teaching of studio-based art to online platforms (Fleischmann, 2020; Kini-Singh, 2020). They are expected to redesign their courses 
and reinvent their pedagogical and assessment approaches (Hassan, 2021) while also trying to minimize or at least understand the challenges that students are facing, such as technical problems and internet access difficulties (Sharma \& Bumb, 2021). According to Pomerantz (as cited in Dancewicz, 2020), shifting classes to online platforms requires educators to rewrite or modify syllabi, learn new technology, use their own devices and data plans, and cater to the diverse needs of their students. Pomerantz (2020) suggested that all these efforts are exerted by educators without clear guidelines or extra payment;

"Art educators are still troubleshooting questions about how to work with students remotely in real-time, and the challenge is opening up existential questions about art as much as logistical ones. These are profound dilemmas that students and instructors are being forced to confront on the spot, and under immense stress: professional, financial, and healthrelated." (Pomerantz, 2020, para. 4)

Since the beginning of the COVID-19 outbreak, art and design educators around the world have explored and applied several approaches to keep students learning while they transition to learning remotely. Their endeavors were experimental as there are hardly any studies that offer suggestions and guidelines for online and blended art and design learning. Many of these educators realized the importance of cooperation and exchanging knowledge about what educational institutions, communities, and countries are currently doing to mitigate the educational impact of the pandemic. Therefore, they attempted to get information, guidance, and post and share their experiences online through blogs, podcasts, Facebook groups, and social media platforms. Some of the professional online resources, tools, platforms, and learning management systems (LMS) that have been and may continue to be effective in helping educators remotely communicate with students and improve their online teaching skills are listed in Tables 1 and 2. The purpose of these tables is to support such process of exchange of experiences and knowledge.

Table 1. Art and design remote teaching resources and tools

\begin{tabular}{|l|l|l|}
\hline Name & Link & Description \\
\hline $\begin{array}{l}\text { YouTube } \\
\text { Windows Ink }\end{array}$ & $\begin{array}{l}\text { https://www.youtube.com } \\
\text { /watch?v=9xIF7INIK0k }\end{array}$ & $\begin{array}{l}\text { Window ink workspace is a tool in } \\
\text { windows 10 which instructors can } \\
\text { use to draw on screen or screenshot, } \\
\text { create sticky notes, or just make quick } \\
\text { sketches. }\end{array}$ \\
\hline $\begin{array}{l}\text { YouTube (How to } \\
\begin{array}{l}\text { Write or Draw } \\
\text { anything on your } \\
\text { Computer Screen) }\end{array}\end{array}$ & $\begin{array}{l}\text { https://www.youtube.com } \\
\text { /watch?v=gmt0029LHSQ } \\
\text { who want to make a tutorial. It } \\
\text { teaches them how to write or draw } \\
\text { anything anywhere on their } \\
\text { computer screen. }\end{array}$ \\
\hline Plaghunter & $\begin{array}{l}\text { https://www.plaghunter.c } \\
\text { om/en/ }\end{array}$ & $\begin{array}{l}\text { Plaghunter is an image plagiarism } \\
\text { website used for professionals and } \\
\text { educators in the visual arts field. }\end{array}$ \\
\hline
\end{tabular}




\begin{tabular}{|c|c|c|}
\hline Name & Link & Description \\
\hline $\begin{array}{l}\text { Adobe Education } \\
\text { Exchange }\end{array}$ & $\begin{array}{l}\text { https://edex.adobe.com/cr } \\
\text { eativity-in-education }\end{array}$ & $\begin{array}{l}\text { The Adobe Education Exchange is a } \\
\text { free learning platform and } \\
\text { community, designed by educators } \\
\text { for educators, to ignite creativity in } \\
\text { the classroom. It includes teaching } \\
\text { resources by grade level and subject } \\
\text { areas. }\end{array}$ \\
\hline Skill Share & $\begin{array}{l}\text { https://www.skillshare.co } \\
\text { m/ }\end{array}$ & Learning Platform \\
\hline $\begin{array}{ll}\text { Free } & \text { Online } \\
\text { Courses } & \end{array}$ & $\begin{array}{l}\text { https://www.coursera.org } \\
\text { /courses?query=free }\end{array}$ & $\begin{array}{llll}\text { Free Online } & \text { Courses } & \text { from } & \text { Top } \\
\text { Universities } & & & \end{array}$ \\
\hline edWeb & https://home.edweb.net/ & $\begin{array}{l}\text { A free professional learning network } \\
\text { for the education community }\end{array}$ \\
\hline Udemy & https://udemy.com/ & Various online courses \\
\hline Netcom Learning & $\begin{array}{l}\text { https://www.netcomlearni } \\
\text { ng.com/ }\end{array}$ & Learning information platform \\
\hline Khan Academy & $\begin{array}{l}\text { https://www.khanacadem } \\
\text { y.org/ }\end{array}$ & $\begin{array}{l}\text { Free online courses, lessons, and } \\
\text { practice worksheets }\end{array}$ \\
\hline GDG MENA & $\begin{array}{l}\text { https://www.youtube.com } \\
\text { /GDGMENA }\end{array}$ & $\begin{array}{l}\text { A platform developed for MENA } \\
\text { educators' support and information }\end{array}$ \\
\hline $\begin{array}{l}\text { Microsoft } \\
\text { Education Centre }\end{array}$ & $\begin{array}{l}\text { https://education.microsof } \\
\text { t.com/en-us }\end{array}$ & $\begin{array}{l}\text { Microsoft Education Centre is } \\
\text { designed for all educators in all fields } \\
\text { and levels to access various courses } \\
\text { and resources within every } \\
\text { educational or training field. }\end{array}$ \\
\hline Masar & https://masar-edu.com/ & $\begin{array}{l}\text { A platform for teaching creative } \\
\text { technology }\end{array}$ \\
\hline $\begin{array}{l}\text { Adobe Max } 2020 \\
\text { Creativity } \\
\text { Conference }\end{array}$ & http://max.adobe.com & $\begin{array}{l}\text { A platform that helps in building } \\
\text { skills in design, video, photography, } \\
\text { illustration }\end{array}$ \\
\hline $\begin{array}{lr}\text { K12 } & \text { Distance } \\
\text { Learning } & \text { Resources } \\
\text { for COVID-19 } \\
\text { Pandemic + PDF - }\end{array}$ & $\begin{array}{l}\text { https:// pikmykid.com/dist } \\
\text { ance-learning-resources/ }\end{array}$ & Distance learning resources \\
\hline TED Ed & www.ed.ted.com & $\begin{array}{l}\text { TED-Ed is an award- } \\
\text { winning education platform that } \\
\text { aims to spark and celebrate the ideas } \\
\text { and knowledge-sharing of teachers } \\
\text { and students around the world. }\end{array}$ \\
\hline Applied HE & www.appliedhe.com & $\begin{array}{l}\text { AppliedHETM Pte Ltd is a Singapore- } \\
\text { based organization that provides } \\
\text { research and strategic } \\
\text { communication services for the } \\
\text { graduate recruitment and higher } \\
\text { education sectors. }\end{array}$ \\
\hline Lynda.com & ww.lynda.com & $\begin{array}{l}\text { Lynda.com is a leading online } \\
\text { learning platform that helps anyone } \\
\text { learn business, software, technology, } \\
\text { and creative skills to achieve personal } \\
\text { and professional goals. }\end{array}$ \\
\hline
\end{tabular}




\begin{tabular}{|l|l|l|}
\hline Name & Link & Description \\
\hline Udacity & www.udacity.com & $\begin{array}{l}\text { Udacity is an online education } \\
\text { provider that offers online courses, } \\
\text { popularly known as Massive Open } \\
\text { Online Courses (MOOCs). It offers a } \\
\text { micro-credential called Nanodegree. }\end{array}$ \\
\hline $\begin{array}{l}\text { Google Teach from } \\
\text { Home }\end{array}$ & $\begin{array}{l}\text { https://teachfromanywher } \\
\text { e.google/intl/en/ }\end{array}$ & $\begin{array}{l}\text { A hub providing information, tips, } \\
\text { training, and tools to help students } \\
\text { and in } \\
\text { remote teaching and learning }\end{array}$ \\
\hline LinkedIn Learning & $\begin{array}{l}\text { www.learning.linkedin.co } \\
\mathrm{m}\end{array}$ & $\begin{array}{l}\text { linkedIn Learning is an on-demand } \\
\text { library of instructional videos } \\
\text { covering the latest business, } \\
\text { technology, and creative skills. }\end{array}$ \\
\hline
\end{tabular}

Table 2. Effective platforms, applications, and tools for remotely teaching art and design

\begin{tabular}{|c|c|c|}
\hline Name & Link & Description \\
\hline $\begin{array}{l}\text { Google } \\
\text { Classroom }\end{array}$ & $\begin{array}{l}\text { www.classroom.google } \\
\text {.com }\end{array}$ & $\begin{array}{l}\text { Google Classroom is a free web-based } \\
\text { platform that integrates the user's G Suite } \\
\text { for an education account with all G Suite } \\
\text { services, including Google Docs, Gmail, } \\
\text { and Google Calendar. It allows users to } \\
\text { create classes, distribute assignments, } \\
\text { communicate, and stay organized. }\end{array}$ \\
\hline Zoom & www.zoom.us & $\begin{array}{l}\text { Zoom provides videotelephony and online } \\
\text { chat services through cloud-based peer-to- } \\
\text { peer software and is used for } \\
\text { teleconferencing, telecommuting, distance } \\
\text { education, and social relations. }\end{array}$ \\
\hline Moodle & www.moodle.org & $\begin{array}{l}\text { Moodle is a learning management system } \\
\text { (LMS) that supports learning and training } \\
\text { needs for a wide range of institutions } \\
\text { across the globe. }\end{array}$ \\
\hline Schoology & www.schoology.com & $\begin{array}{l}\text { Schoology is a virtual learning } \\
\text { environment and social networking } \\
\text { service that allows users to create, manage, } \\
\text { and share academic content. }\end{array}$ \\
\hline Kadenze & www.kadenze.com & $\begin{array}{l}\text { Kadenze is a massive open online course } \\
\text { provider that offers courses in art, music, } \\
\text { and creative technology. }\end{array}$ \\
\hline Remind & www.remind.com & $\begin{array}{l}\text { Remind is a communication platform that } \\
\text { helps educators reach students and } \\
\text { parents by allowing them to send } \\
\text { messages to an entire class, a small group, } \\
\text { or just a single student. }\end{array}$ \\
\hline Class Dojo & www.classdojo.com & $\begin{array}{l}\text { ClassDojo is a school communication } \\
\text { platform that teachers, students, and } \\
\text { families use to build communities and } \\
\text { share the classroom content. }\end{array}$ \\
\hline
\end{tabular}




\begin{tabular}{|l|l|l|}
\hline Name & Link & Description \\
\hline Web Paint & https://web-paint.com & $\begin{array}{l}\text { Web Paint is a Chrome extension that } \\
\text { provides effective tools to draw, add text, } \\
\text { and annotate on live web pages. }\end{array}$ \\
\hline Seasaw & www.web.seesaw.me & $\begin{array}{l}\text { Screencastify is a free Chrome extension } \\
\text { that allows the user to record, edit, and } \\
\text { share videos. }\end{array}$ \\
\hline Flipgrid & $\begin{array}{l}\text { Seesaw is a platform that allows students } \\
\text { to take pictures, draw, record videos, and } \\
\text { more to capture learning in a portfolio. It } \\
\text { also allows teachers to find or create } \\
\text { activities to share with students. }\end{array}$ \\
\hline Adobe Spark & www.flipgrid.com & $\begin{array}{l}\text { Flipgrid is a video response platform } \\
\text { where educators can have online video } \\
\text { discussions and feedback with students or } \\
\text { other educators. Students can also provide } \\
\text { feedback to one another. }\end{array}$ \\
\hline
\end{tabular}

In addition to all the above-listed platforms and tools, Google in collaboration with UNESCO's Institute for Information Technologies launched "Teach from Home", which is a hub of resources and tools to assist educators during the coronavirus pandemic. The resources, tools, and tips help educators learn how to teach and communicate with students remotely and how to collaborate with other educators $(\mathrm{Li}, 2020)$.

Some researchers believe that social distancing and the limitations in the ability to meet in the classroom during the pandemic "will likely limit opportunities for students to learn" (Daniel, 2020). Other researchers believe that online learning created many opportunities and led to various advantages including "easy accessibility, cost-effectiveness, personalized learning, development of cognitive abilities, prompting computer skills, developing self-pacing, and accessing globalization" (Mukuna \& Aloka, 2020, p.136). Although art and design educators have been struggling to emulate their hands-on face-to-face teaching experiences and many of them struggled to overcome the limitations of virtual environments, there is no doubt that these virtual environments have offered a wide range of online activities and opportunities (Ferri et al., 2020). If utilized innovatively and wisely, these online platforms and tools can help educators design experiences and create opportunities that were not possible through face-to-face conventional teaching. Virtual environments allow for a variety of activities that can augment the learning experience. These activities include the following: blogging and vlogging, collaborative writing or story-making, content production, discussion forums, e-portfolios, gamification, mind-mapping, multimedia presentations, online drawing and sketching, video chatting and conferencing, video production and sharing, virtual galleries, using anti-plagiarism tools, online assessment, surveys, and webinars (International Baccalaureate Organization, 2020). Another 
opportunity that was not possible through face-to-face teaching is asynchronous learning which allows teachers to record their lectures. This allows learners to learn at their own pace, and to access the educational material whenever they need it at any time and place. Thus, students sometimes learn asynchronously and/or synchronously and collaboratively at the same time with other online learners. Moreover, distance learning allows for the interaction between the educator and students, and also among the students through chat and instant messaging, or audio and video meetings, which helps with continuous follow-up and personalization of the whole learning experience. As a result, with all its audio-visual resources, illustrations, and animations, distance education has transformed the learning experience into a more interactive one accompanied by visual and audio effects that make the "static" educational process more attractive and engaging.

Online platforms also opened for art and design students further opportunities such as exhibiting their designs and artworks in virtual galleries and sharing content and discussion with wider audiences across the world. There are several websites and applications that allow students to create online art galleries, virtual exhibitions, and 3D tours. These include Kuula (https://kuula.co/), Kunstmatrix Art.Spaces (https://artspaces.kunstmatrix.com/en), deviantArt (https://www.deviantart.com/), and 3D Vista (https://www.3dvista.com/). In addition to the aforementioned platforms, Adobe Captivate (https:/ / www.adobe.com/ products/ captivate.html\#x) allows for the creation of virtual reality walkthroughs.

Fotaris et al. (2015) conducted a study that explores the use of deviantArt, an online art gallery platform, as an online teaching platform for a postgraduate course in Graphic Design at the Hellenic Open University. The study revealed that the online teaching experience had an impact on enhancing learning and motivating design students to propose ideas, collaborate and communicate. This online experience revealed some advantages; it allowed the creation of online portfolios for public exposure; it assisted students in overcoming their fear of public exposure; it facilitated social interaction and communication among students and the public; it strengthened the university's online presence in the design community; it facilitated and encouraged peer-reviewing and peerfeedback, thus allowing students to reflect on their practice.

Other opportunities and advantages of teaching art and design remotely include the creation of breakout groups which allows for teamwork and informal gatherings of a team of students to work collaboratively and discuss design problems during studio hours. Breakout groups also allow for peer review, which encourages social interaction among students and enhances their engagement in collaborative problem-solving (Fotaris et al., 2015). Moreover, panels that judge students' artworks or graduation projects may consist of geographically distributed experts and lecturers. In addition, the possibility of asynchronous communication through online learning increases the flexibility of instructors' work schedules. Despite all the aforementioned advantages, Fotaris et al. (2015) stated the following disadvantages: 
"[...] as the size of virtual classes tends to be larger than that of the physical ones and written communication tends to be more timeconsuming than its oral counterpart, the large amount of data they are required to process and the amount of feedback they must generate increase their workload [31]. [...]. A further issue to consider is the manner in which a reliance on asynchronous communication may affect students: since feedback from both tutors and peers may no longer be immediate, the development of subsequent drafts may stall or temporarily continue in the absence of feedback [32]. This issue may be compounded by a reduced overall engagement with the peer group due to" "assessors of online portfolios do not always have the opportunity to see the student's complete portfolio at a glance." (Fotaris et al., 2015, p.5)

Other advantages that Fotaris et al. (2015) found include issues that may negatively affect assessment and the evaluation process. They stressed that in a virtual environment, the designs and artworks are often viewed in sequence and "cannot be easily cross-referenced". Moreover, in contrast to the high-resolution designs and artworks submitted and displayed in a hardcopy format to the instructor in a face-to-face setting, digital images usually have low-resolution and unclear details. Fotaris et al. (2015) also believe that the process of designing digital drafts of any design idea or concept is more time-consuming than spontaneously hand-drawing sketches of the idea. Consequently, the process of brainstorming, which is hindered or limited by time constraints associated with the use of software to create sketches, may be less productive. It may lead to more superficial ideas in comparison to the ideas generated during face-to-face brainstorming and sketching. Additionally, instructors usually complain that teaching online can be more demanding and time-consuming than teaching faceto-face and that it considerably increased their workload (Fotaris et al., 2015). Thus, teachers may face significant challenges as they may feel fatigue and stress due to the rapid professional development that they have to undergo while teaching remotely and the overwhelming exposure to a variety of platforms and technical issues (International Baccalaureate Organization, 2020). However, reduced academic and administrative load can help educators transition more easily. According to Alea et al. (2020), the challenges that educators face and their readiness to distance learning education vary from one educator to another depending on gender, length of teaching experience, and geographic location.

The above challenges and disadvantages led some researchers (Fotaris et al., 2015) to emphasize the advantages of face-to-face learning and stress the difference between it and online learning as follows:

"The design studio differs from the typical classroom by being primarily a space for production, personal discussions, and experimentation with materials and tools, which takes places in a setting replete with drawing boards, work-benches, stools, papers, images, models, as well as other teaching aids (Fotaris et al., 2015). In this setting, students develop sensitivities to a number of fundamental yet volatile elements of design education such as problem-based learning, teamwork, sensitivity to market opportunities, and the ability to generate innovation while they create, exhibit, and discuss their work with their peers (Fotaris et al., 
2015). The emphasis on this kind of communication and cooperation constitutes the main feature that distinguishes this particular environment from that of a classroom or lecture theatre." (Fotaris et al., 2015, p.2)

For the above-listed reasons, Fotaris et al. (2015) believe that there is currently no virtual teaching platform or environment that can replicate the design studio experience. They also state that existing platforms do not recognize social engagement as a vital element to the overall learning experience.

A previous study by Baker et al. (2016) about art educators' perceptions of elearning revealed "dissonance between eLearning and the nature of Arts education, negatively perceived reasons for teaching education in an eLearning mode, and some expressions of positive experiences in this space." The study investigated the perceptions of academics from sixteen Australian universities and explored their experiences and attitudes towards teaching Arts in an eLearning mode. The academics who participated in the study expressed the belief that e-learning complements and does not replace face-to-face learning (Baker et al., 2016). On the other hand, Li and Lalani (2020) suggest that learning online can be as effective or even more effective than face-to-face learning as they stated the following in an article published by the World Economic Forum;

"For those who do have access to the right technology, there is evidence that learning online can be more effective in a number of ways. Some research shows that on average, students retain $25-60 \%$ more material when learning online compared to only $8-10 \%$ in a classroom. This is mostly due to the students being able to learn faster online; e-learning requires $40-60 \%$ less time to learn than in a traditional classroom setting because students can learn at their own pace, going back and re-reading, skipping, or accelerating through concepts as they choose." (Li \& Lalani, 2020, para. 15).

Li and Lalani (2020) believe that the pandemic has disrupted an education system that was already losing its relevance due to focus on traditional academic skills rather than on critical thinking skills, which are considered more important for success in today's market. They suggest that the move to e-learning may be the catalyst to create a new, more effective approach to education.

Unlike Li and Lalani, the perception of the effectiveness of e-learning by Fotaris, et al. (2015) is conditional and depends on the level and extent of familiarity of the educators and students with ICT, as well as on the way a number of additional issues are dealt with and addressed;

"These include the high cost of computing equipment, the need for constant upgrades and technical support, the occasional lack of compatibility between different applications, the potential unreliability of a large number of online sources, etc. The evaluation stage has the potential to prove particularly problematic, as the interaction between participants may fail to match the richness and immediacy available in the traditional design studio due to limited screen resolution, insufficient bandwidth, and - most importantly - the psychological and practical 
constraints imposed by virtual communication." (Fotaris, et al., 2015: p.6).

Nevertheless, e-learning can be effective if educators follow productive guidelines such as the guidelines which were recommended by the International Baccalaureate Organization (2020) to design and evaluate online work. These recommendations advised educators to use more collaborative projects and formative assessments that are designed to get students to collaborate and work in teams. It is also advisable to encourage students as well as educators to utilize online resources and tools. Educators, for instance, may consider using MOOCs (massive open online courses), which make content reachable for everyone and allow students to access complete courses offered by world-renowned universities (Haba \& Dastane, 2019). The use of plagiarism checkers is also recommended as it can help educators automatically check students' submissions. Another recommendation is to design assignments and assessed content that encourage students to embed their experiences and surrounding into their designs or artworks.

\section{Method}

\subsection{Research Design and Participants}

In this study, a qualitative approach was adopted by employing and conducting an online focus group through Microsoft Teams with a purposive sample of five Fine Arts and six Graphic Design instructors ( $N=11$, seven males and four females) in the BA Art and Design program at the University of Bahrain. The participants were selected using purposive sampling as they were teaching at the University of Bahrain during the second semester of the academic year 2020-2021 when the study was conducted. Their experiences were considered relevant to enable comparison between pre-COVID and COVID-19 teaching experiences. The participants' higher education teaching experience ranged from 1 to 21 years. Focus groups are a method of collecting research data through informal group discussions on a specific topic, which allow participants to discuss, agree, and disagree with each other's opinions (Reimers \& Schleicher, 2020). This qualitative approach was adopted because it was applicable to the study as it allows for interaction and generating discussion between participants in order to collect qualitative data around specific issues (Flynn et al., 2018). It also allows for observation of "group dynamics and levels of consensus and to gather information on contextual factors" (Flynn et al., 2018, p. 2). Thus, for our research purpose, the focus group was a relevant data collection method to capture educators' insights about the online teaching experience through writing field notes and observations regarding their experiences before coding these experiences using qualitative content analysis.

\subsection{Data Collection Instruments}

The focus group, which was held for four hours divided into two sessions over two weeks, involved a discussion that was based on open-ended questions aimed to assess the following main themes: educators' emerging educational needs, experiences, implementation challenges, and evolving teaching and assessment approaches. These themes were generated through reviewing all the research 
questions and objectives to identify the broad reasons behind the study. The focus group discussion was recorded in Microsoft Teams and then transcribed. Using Microsoft Teams allowed for collecting data and writing field notes in real-time, while observing the interaction among the participants (Flynn et al., 2018). Keywords and recurring ideas by the participants were identified to draw comparisons and conclusions. Data collection also involved note-taking and participant observation, which yielded qualitative results and observational data. This study was completed over a one-semester period. The findings were shared with the participants to validate the results, and consent forms were signed by all of them to indicate their approval to participate and to allow their names to be used in this study.

\section{Findings: An Evaluation of Educators' Experiences, Challenges, and Perceptions of Distance Education in Art and Design}

This section presents a critical review and evaluation of the educators' experiences of online education in art and design based upon the focus groups and the qualitative analysis of collected data. The focus group involved a discussion about the challenges created by the transition to online learning, about the educators' responses to those challenges, and about resources that they attempted to use to advance education through effective and alternative tools, approaches, and means. All discussions in the focus group were recorded, transcribed, and then analyzed.

Art and design professors were questioned about their experiences and the challenges they faced during the second semester of the academic year 2020-2021 and their perceptions of teaching virtually. The discussion also revolved around the most appropriate means of evaluating student learning outcomes, skills, knowledge, and competencies acquired through the virtual learning environment.

Since its transition to distance education, the University of Bahrain (UOB) has kept pace with other prestigious universities in terms of providing the latest technologies and the best online platforms and learning management systems (LMS). Over the first nine months of the pandemic, UOB has offered virtual workshops to its professors to train them on the use of Blackboard Ultra and Microsoft Teams. Instructors and students were able to access the platforms via their personal computers as well as their mobile phones.

The aim of the focus group was to exchange experiences, strategies, and innovative solutions that the professors have employed to teach art and design remotely.

\subsection{Educators' Challenges and Experiences of Online Education in Art and Design}

Dr. Jameela Sadoun stated that in her experience of teaching topics of a fully practical nature that require special skills (such as studio art) there were clear limitations in comparison to other topics. She added that art professors have used a variety of educational methods in the past, but they mostly adhered to the 
traditional face-to-face approach especially while teaching studio courses that heavily relied on assessing the individual skills of students while developing the artwork. In such courses, teachers have to observe the student's work in a true form which can only be done accurately with the naked eye. For this reason, elearning was used modestly in this field prior to the Covid-19 pandemic. The safety and health procedures brought on by the pandemic, including the use of remote education, created many difficulties for teachers of practice-based courses. According to Dr. Sadoun, assessing students' artworks remotely is quite challenging as it highly depends on the clarity of the image, angle of photography, and the lighting source. She emphasized that "providing feedback" remotely is a significant challenge faced by fine arts professors and that students typically provide several sketches for the same topic to demonstrate their skills. This places additional pressure on the professors to provide accurate and insightful feedback on a large number of sketches based on remote observations. Despite all the challenges, Dr. Sadoun believes that using remote learning for an extended period of time will eventually force all participants to adapt and learn to utilize this new way of teaching in a more effective manner which will positively reflect on the learning outcomes.

Most of the educators did face issues with remote teaching. Thus, the focus group helped these educators exchange their teaching challenges, brainstorm possible remedies, and provide emotional and technical support to each other.

In the case of Mr. Shah, he highlighted recurring technical issues faced by some students and how he came up with creative solutions for them. Some students were not able to hear the lecture online. A group of those eventually managed to fix the problem by changing the microphone or changing the technical settings. Others resorted to watching the live-streamed lecture without sound, and afterward watching the recorded lecture in order to hear the instructor's voice clearly. Mr. Shah tried to assist the students by searching for tutorial videos on YouTube that discuss how to troubleshoot various technical issues on Blackboard. Another problem highlighted by Mr. Shah relates to assignment submissions. After submitting their assignments, some students discovered that the instructor did not receive them. As a solution, the instructor agreed to send confirmation emails to the students within one day of submission. Students who do not receive a confirmation email have to resubmit the assignment or contact IT support in order to resolve the issue.

In another example, Mr. Shah taught a practical course about color separation and print design which involved a hands-on approach to do lithography printing. The instructor was worried about the possibility of plagiarism. He feared that some students might download artwork from the internet and submit it. His approach was to require all students to submit a time-lapse video recording while performing all the steps until the final artwork is developed. These time-lapse videos turned out to be a good collection for the students' portfolios. Mr. Shah also noted that online teaching allowed him to focus on lecturing without needing to move around the class from one student to another. Despite the obvious ease of teaching in this manner, there is also an inherent drawback. The instructor 
cannot determine if the students are paying attention and following his step-bystep instructions. His strategy was to regularly ask students whether they understood his instructions or not. Every ten minutes Mr. Shah would pick a random student to share his/her screen with the rest of the class and repeat the last steps performed by the instructor. This approach ensures that students interact with the instructor and thus have a better chance of understanding the course content.

Mr. Bin Mukhtar stressed that using online teaching for animation or design presents a new set of challenges including the risk of plagiarism. However, while teaching the "Portfolio Development" course, he faced a unique problem. This course requires him to conduct mock job interviews with students and to give them one-to-one feedback. This resulted in prolonging the duration of the class well beyond the specified timing. Students resorted to one of the built-in features in MS Teams which is the ability to record interviews and watch them at a later time. This allowed them to observe their own behavior and conduct selfevaluation on their performance during these interview sessions. These recordings can be accessed by the students and also by the instructor, hence facilitating the assessment process. Mr. Bin Mukhtar utilized the recording feature in MS Teams in a different way. He recorded 30-minute tutorials before the class starts and uploaded them to MS Teams. Students started watching the pre-recorded videos before the lecture. He stated, "During the lecture, I would repeat the same content that was in the pre-recorded video, but the difference is that during the lecture the students can stop me and ask me at any time." Another challenge that Mr.Bin Mukhtar's graphic design students faced is that their internship had to be done online instead of through personal attendance in a design agency. He stated that some agencies requested students who wish to do their internships online to complete more working hours than what they would normally complete if they would work in the office.

\subsection{Educators' Strategies and Suggestions to Overcome the Challenges of Online Education in Art and Design}

Despite all the challenges they encountered, the educators employed or at least suggested effective strategies to deal with their difficulties. For instance, in order to overcome the above-mentioned problem with internships, Dr. Abuelinin suggested giving students elective courses that test their skills as a replacement for internships. Moreover, Dr. Abuelinin suggested a number of recommendations that can facilitate online teaching of art and design; All students need to be prepared to open their cameras and share their screens if required. The IT Department needs to make technical support readily available to help students install software and handle technical issues. Graphic design students tend to use a lot of software such as 3D Max, Maya, and Adobe After Effects. This places additional pressure on the ICT support team. They might even resort to using remote-access software to resolve technical issues directly on the students' devices (after taking their permission).

Dr. Abuelinin believes that Blackboard has clear limitations when it comes to art and design students. It does not allow graphic design students to upload large graphic files. In comparison, Moodle has some features that are more suitable to 
the needs of art and design students, including cloud storage that is better suited to saving large files. A cloud-based system is a much better option than the university server when it comes to uploading larger design files and materials. Dr. Abuelinin, suggests adding cloud-based features to Blackboard or replacing it with a cloud-centric platform. Meanwhile, he managed to overcome these limitations by utilizing Google Drive for large-file transfers. He also mentioned that it is not easy to create a duplicate of course materials on Blackboard in order to customize them for another section of each class.

In the case of Dr. Sadoun, she tried to overcome the challenges she faced in online teaching by learning how to perform video editing. She wanted to make concise and brief video tutorials. This requires a fair bit of knowledge of video-editing techniques. She felt that "as an art teacher" she should not need to address such "technical matters", which ultimately hinder her ability to properly communicate with students. Dr. Sadoun also expressed her frustration with another aspect of online teaching. She is looking for a tool or plugin that would allow her to virtually draw on her students' paintings or sketches during live online classes. Currently, she asks students to upload images of their sketches, which she would then take time to download before opening them in a photo-editing program to draw on top of them using the Wacom pen. This workaround is very timeconsuming and limits her ability to give feedback in a timely effective manner. Dr. Sadoun believes there are digital tools and applications that facilitate giving remote feedback to art students to show them how to enhance certain aspects of their work such as proportion, lighting, shading, and anatomy.

Dr. Abulainin, who faced similar challenges in video editing, recommends the use of Microsoft Video Maker as an easy solution for art teachers to edit their videos. He also recommends conducting e-learning content development workshops for educators to teach them how to create, develop, and edit e-learning content and applications rather than only concentrating on workshops that aim to teach educators how to use LMS.

Dr. Al Abed, who also teaches fine arts courses, agreed with Dr. Sadoun in stressing the difficulty of giving remote feedback to students, for example, feedback relating to the warmth or coldness of the colors in a painting. They both had cases where students insist that the colors, in reality, have a different value or are warmer or colder than the way they appear on the screen. In these cases, instructors can become confused and unable to precisely and confidently give the feedback that their students require.

Ms. Al Mahdi, who teaches graphic design courses, faced both technical and also social challenges. She found it difficult to teach students without knowing how they look like, without associating a face with the name, and without having faceto-face interactions with them. Her solution was to ask students to film a short video in which they introduce themselves to her and the other students. On the technical front, Ms. Al Mahdi was frustrated with the Blackboard platform because it does not display the lecture recordings immediately for students who missed the start of the lecture and wish to catch up in real-time. The platform 
takes some time for the videos to be uploaded and displayed on the recorded session's page. Despite such challenges, she believes that online learning does present certain benefits such as eliminating any wastage in commute time. Working and learning from home helped students gain more time and this led to better learning outcomes and an improvement in the quality of their projects. In her opinion, such benefits offset the risk of cheating by some students who receive assistance from professional designers or painters in preparing their art projects. This concern was reiterated by many other educators. Their recommendation to minimize the chances of cheating is to ask students to switch their cameras on while painting or designing during the lecture or to ask students to submit a timelapse video that displays the various stages of their project work.

A creative strategy adopted by Ms. Al Mahdi was to challenge students to complete their artwork within a time limit. This led to higher levels of interaction with students and ensured that they remain in front of the screen during the lecture.

Despite all the stated challenges, most of the instructors agreed that there are some advantages to online education. Dr. Sadoun thinks that the improved learning outcomes she noticed in her students might be due to the availability of the lecture recordings, which allow students to go back to any part that they might have missed or forgotten. The availability of these recordings also allows students to concentrate on understanding and absorbing the material rather than on taking notes during the lecture. Dr. Sadoun also thinks that the variety of assessment methods that online education can offer allowed students to have more opportunities to demonstrate their talents and aptitudes, and allowed instructors to further breakdown their grading methodology, and eventually led to better learning outcomes.

\section{Discussion and Recommendations}

In relation to the aforementioned findings, some of the challenges reported by the participants of this study partly resonate with what previous studies have revealed. Previous studies, for example, also found that academic integrity is considered worrisome to art and design educators who teach remotely in other parts of the world. Tusiime et al. (2020), for instance, indicated that online teaching may encourage educators as well as students to plagiarize electronic content. They also stated that some educators believe that the availability of online content and artworks for students to copy can hinder their ability to innovate and produce creative artworks. On the other hand, it makes it more challenging for educators to ensure the academic integrity and originality of students' artworks (Tusiime et al., 2020). In their study, Tusiime et al. (2020) revealed that one of the factors that helped art and design educators mitigate the challenges of distance education is encouragement, motivation, and support from their peers who taught them how to improve their digital skills. Another factor is the training and technical support they received to improve their digital skills and know how to deal with the technical issues they faced. 
The findings also indicate that the participants in this study have used effective strategies to cope with the existing challenges. One of these strategies was to ask students to submit a time-lapse video recording while executing their projects in order to ensure academic integrity. Another effective strategy is recording asynchronous tutorials for students to watch before the class starts. During the lecture, educators may repeat the same content that was in the pre-recorded video but would have more time to focus on answering students' questions. Additionally, to overcome challenges related to difficulties in encouraging students to interact with each other or to become socially comfortable and responsive during virtual lectures, a good strategy is to ask them to record a short video in which they introduce themselves to their instructors and peers.

Despite all the experimental strategies that art and design educators have so far employed to cope with the challenges they face during distance education, there is an urgent need to further address these challenges and to optimize their online pedagogical practices. Therefore, this study offers several recommendations to guide the development of an art and design education strategy during the pandemic. One of the recommendations is to create a learning management system or online learning platform (such as Kadenze) tailored for art and design courses and or to add to existing learning management systems all the features and tools that art and design students need (Kini-Singh, 2020). Kadenze is a platform that has a network of design schools and contains special art and design features and tools that allow users to upload portfolios of their artworks and designs in addition to allowing them to create virtual galleries and museums. According to Straumsheim (as cited in Kini-Singh, 2020):

"Kadenze is both a MOOC provider as well as an online program management company and while it offers free courses like Coursera or edX, it also provides partners with instructional designers and animators for help on the production aspect of online education." (p.5)

Recently, Kadenze partnered with many international art and design schools and programs, including California College of the Arts, California Institute of the Arts, Rhode Island School of Design, Princeton, Stanford, and more (Kini-Singh, 2020).

Another recommendation is to conduct e-learning content development workshops for educators to teach them how to create, develop, and edit e-learning content and applications (Tusiime et al., 2020). Kini-Sing (2020) believes that training can help art educators in transitioning from face-to-face teaching to the "creation and production of online or video content that would be as effective as in-person learning" (p.9). This can be further supported by another recommendation, which is to create an online educational platform that includes webinars and educational video lessons for art and design professors and students in Bahrain and the Arab world.

In addition, it is important to form a technical support team to provide solutions for all students and instructors (Tusiime et al., 2020). Before the commencement of the academic semester, this team may communicate with students and ensure that they are ready, and have installed all required software, and do not face any technical problems. This team may also have suitable software to access students' 
devices, upon their request and approval, and remotely fix any technical issues they face.

Another recommendation is to create a community of art and design faculty open to sharing their online teaching strategies and learning together. This community can collaborate in forming a database of resources or educational materials. In Morocco, for instance, the Ministry of Education in collaboration with the Centre National pour la Recherche Scientifique et Technique (CNRST) created a national database for instructors to upload their recorded lectures, educational materials, and other resources (Kini-Singh, 2020). In addition, researchers have suggested forming online groups for sharing coauthored blogs about online learning and art education (Kini-Singh, 2020).

In addition to all the above-mentioned recommendations, higher education institutions must provide art and design educators with access to adequate tools and technologies to support their online teaching endeavors. These may include but are not limited to digital cameras, video and audio recording tools, and screencasting tools for creating their educational content (Minnesota Department of Education, 2021).

The above-listed recommendations are intended to support education leaders and authorities at various academic institutions in Bahrain and in the region, in formulating adaptive and effective responses to a crisis that will significantly change the way art and design are taught globally.

\section{Conclusion}

As universities transition to virtual education, exploring effective practices for teaching art and design students remotely has become crucial. It is critically important to study the strategies that universities employ to efficiently transfer skills and knowledge and meet students' needs through an online learning environment. Art and Design classes include practical and hands-on activities that cannot easily be met in digital settings and environments. Therefore, this paper explored the creative methods adopted by art and design professors to move to remote teaching during the pandemic in order to identify the most effective practices that educators could employ in educational institutions in Bahrain to engage students and enhance the distance learning process.

Many art and design educators sought various approaches to provide the best possible learning experiences for students despite the limitations of distance education. The instant transition to online learning challenged traditional notions of art and design education and altered instructors' and students' views and perceptions of e-learning. In order to explore these perceptions, this paper investigated the implementation of distance learning in the University of Bahrain using focus group discussions with a purposive sample of eleven art and design academics. Based on an in-depth analysis of these discussions and an investigation into the educators' experiences, challenges, and needs, the findings indicate several challenges facing art and design professors while they attempt to depend on online education as an alternative modality. The challenges reported 
by the majority of participants include technical problems, possible lack of academic integrity and honesty in some of the work that students do offline, difficulty in clearly seeing and evaluating the actual value and warmth of the colors in a student's painting on the screen, and the unavailability of tools and features that specifically support fine arts and graphic design online education in the currently available e-learning platforms and learning management systems. Yet, while the pandemic posed some challenges to art and design educators and their students, it also provided promising opportunities and innovative practices to reshape art education. Through applying the recommendations discussed in this paper, the challenges may be minimized, and the distance education experience can be augmented through online forums and discussions, animated lessons, virtual galleries, and online interactions with artists and designers from all over the world.

\section{Acknowledgments}

I would like to express my gratitude and appreciation for the tireless efforts of the art and design educators at the University of Bahrain who have worked together to implement the best possible approaches to remotely teach art and design during the difficult circumstances of Covid-19. I especially thank them for their unwavering commitment and willingness to engage in a thoughtful, frank, and meaningful dialogue about how to meet the needs of the students in the best possible way in these unprecedented times and circumstances. Their experiences and opinions helped me formulate the important recommendations in this paper. I would also like to give special thanks to Ms. Dallal Al Sindi for helping me in preparing a list of useful online resources to inform the professional development plans and enhance the skills of art and design professors.

\section{References}

Alea, L. A., Fabrea, M. F., Roldan, R. D. A., \& Farooqi, A. Z. (2020). Teachers' covid-19 awareness, distance learning education experiences and perceptions towards institutional readiness and challenges. International Journal of Learning, Teaching and Educational Research, 19(6), 127-144. https:/ / doi.org/10.26803/ijlter.19.6.8

Baker, W. J., Hunter, M., \& Thomas, S. (2016). Arts Education Academics' Perceptions of eLearning \& Teaching in Australian Early Childhood and Primary ITE Degrees. Australian Journal of Teacher Education, 41(11), 31-43. http://dx.doi.org/10.14221/ajte.2016v41n11.3

Dancewicz, K. (2020, April 17). Can You Teach Art Online?. Art in America. https://www.artnews.com/art-in-america/features/teaching-art-online-covid19-professors-strategies-1202684147/

Daniel, S. J. (2020). Education and the Covid 19 pandemic. Prospects, 49, 91-96. https://doi.org/10.1007/s11125-020-09464-3

Dilmaç, S. (2020). Students' Opinions about the Distance Education to Art and Design Courses in the Pandemic Process. World Journal of Education, 10(3), 113. https://doi.org/10.5430/wje.v10n3p113

Ferri, F., Grifoni, P., \& Guzzo, T. (2020). Online Learning and Emergency Remote Teaching: Opportunities and Challenges in Emergency Situations. Societies, 10(4), 86. https://doi.org/10.3390/soc10040086 
Fleischmann, K. (2020). Hands-on versus virtual: Reshaping the design classroom with blended learning. Arts and Humanities in Higher Education, 20(1), 87-112. https://doi.org/10.1177/1474022220906393

Flynn, R., Albrecht, L., \& Scott, S. D. (2018). Two Approaches to Focus Group Data Collection for Qualitative Health Research: Maximizing Resources and Data Quality. International Journal of Qualitative Methods. https:// doi.org/10.1177/1609406917750781

Fotaris, P., Mavrommati, I., Mastoras, T., \& Leinfellner, R. (2015, July 6-8). Teaching Design from a Distance: A Case Study of Virtual Design Studio Teaching via a Social Network. 7th International Conference on Education and New Learning Technologies EDULEARN157th International Conference on Education and New Learning Technologies EDULEARN15 (pp. 4603-4613). Barcelona, Spain: IATED Academy.

Haba, H. F., \& Dastane, O. (2019). Massive Open Online Courses (MOOCs)Understanding Online Learners' Preferences and Experiences. International Journal of Learning, Teaching and Educational Research, 18(8), 227-242. https://doi.org/10.26803/ijlter.18.8.14

Hassan, M. (2021). Online Teaching Challenges during COVID-19 Pandemic. International Journal of Information and Education Technology, 11(1), 41-46. https://doi.org/10.18178/ijiet.2021.11.1.1487

International Baccalaureate Organization. (2020, March). "Online learning, teaching and education continuity planning for schools". https://www.ibo.org/globalassets/news-assets/coronavirus/online-learningcontinuity-planning-en.pdf

Kini-Singh, A. (2020). Art Education in the Time of a Pandemic :The Good, the Challenge, and the Future. Encountering Design Education Online From Place to Space. http://www.unboundjournal.in/wp-content/uploads/2020/08/Amita_KiniSingh_03_Critiques.pdf

Lapada, A. A., Miguel, F.F., Robledo, D. A. R., \& Alam, Z. F. (2020). Teachers' covid 19 awareness, distance learning education experiences and perceptions towards institutional readiness and challenges. International Journal of Learning, Teaching and Educational Research, 19(6), 127-144. https://doi.org/10.26803/ijlter.19.6.8

Li, A. (2020, March 20). Google compiles remote learning resources for educators with 'Teach from Home' hub. 9to5google. https://9to5google.com/2020/03/20/google-teachfrom-home/

Li, C. \& Lalani, F. (2020, April 29). The COVID-19 pandemic has changed education forever. This is how. World Economic Forum. https://www.weforum.org/agenda/2020/04/coronavirus-education-globalcovid19-online-digital-learning/

Li, Y., Zhang, X., Dai, D.Y. \& Hu, W. (2021). Curriculum Innovation in Times of the COVID-19 Pandemic: The Thinking-Based Instruction Theory and Its $\begin{array}{llll}\text { Application. Frontiers } & \text { Psychology, 12, }\end{array}$ https://doi.org/10.3389/fpsyg.2021.601607

Meyer, M.W. \& Norman, N. (2020). Changing Design Education for the 21st Century. She Ji: The Journal of Design, Economics, and Innovation, 6(1), 13-50. https://doi.org/10.1016/j.sheji.2019.12.002

Minnesota Department of Education (2021, April 5). Arts Education in the 2020-21 School Year: Recommendations and Resources. Mn department of education. https://education.mn.gov/mdeprod/idcplg?IdcService=GET_FILE\&dDocNam $\mathrm{e}=\mathrm{MDE} 033530 \&$ RevisionSelectionMethod=latestReleased \&Rendition=primary

Mukuna, R. \& Aloka, P.J.O. (2020). Exploring Educators' Challenges of Online Learning in Covid-19 at a Rural School, South Africa. International Journal of Learning, 
$\begin{array}{llll}\text { Teaching and Educational Research, 19(10), 134-149. } & \text {. }\end{array}$ https://doi.org/10.26803/ijlter.19.10.8

Muftahu, M. (2020) Higher Education and Covid-19 Pandemic: Matters arising and the challenges of sustaining academic programs in developing African universities. International Journal of Educational Research Review, 5(4), 417-423. https://doi.org/10.24331/ijere.776470

Nili, A., Tate, M., \& Johnstone, D. (2017). A framework and approach for analysis of focus group data in information systems research. Communications of the Association for Information Systems, 40(1), 1-21. https:/ / doi.org/10.17705/1CAIS.04001

Öçal, T., Halmatov, M. \& Ata, S. (2021). Distance education in COVID-19 pandemic: An evaluation of parent's, child's and teacher's competencies. Education and Information Technologies, 1-21. https://doi.org/10.1007/s10639-021-10551-x

Pomerantz, K. (2020). Teaching Art Online Under COVID-19. https://hyperallergic.com/547986/teaching-art-online-under-covid-19/

Rasheed, R. A., Kamsin, A., \& Abdullah, N. A. (2020). Challenges in the online component of blended learning: A systematic review. Computers $\mathcal{E}$ Education, 144, 103701. https://doi.org/10.1016/j.compedu.2019.103701

Reimers, F. M., \& Schleicher, A. (2020). A framework to guide an education response to the COVID-19 Pandemic of 2020. OECD. https://read.oecdilibrary.org/view/?ref=126_126988-t631xosohs\&title=A-framework-to-guide-aneducation-response-to-the-Covid-19-Pandemic-of-2020

Sharma, S., \& Bumb, A. (2021). The Challenges Faced in Technology-Driven Classes During COVID 19. International Journal of Distance Education Technologies, 19(1), 1739. https://doi.org/10.4018/IJDET.20210101.oa2

Tabieh, A., Hamzeh, M., Abu-Foudeh, B., Jarrar, N., Al-Manaseer, S., Al-Shawabkeh, A., \& Seikaly, R. (2021). Digital Literacy and its Acquisition by Teachers and Principals at Educational Workplaces. International Journal of Learning, Teaching and Educational Research, 20 (5), 38-55. https://doi.org/10.26803/ijlter.20.5.3

Tusiime, W. E., Johannesen, M. \& Gudmundsdottir, G. B. (2020). Teaching art and design in a digital age: challenges facing Ugandan teacher educators. Journal of Vocational Education \& Training, 1-21. https://doi.org/10.1080/13636820.2020.1786439 